\title{
Experimental Measurement of Temperature Gradient during Bone Drilling in Cameroon, Sub-Sahara Africa
}

\author{
Jean Gustave Tsiagadigui ${ }^{1,2 *}$, Vyek Yaya ${ }^{2}$, Benoit Ndiwe $^{2}$, Ebanda Fabien Betene ${ }^{2}$, Ebenezer Njeugna ${ }^{2}$ and Maurice $^{2}$ \\ Aurelien Sosso ${ }^{1}$
}

${ }^{1}$ Department of Surgery and Specialties, Faculty of Medicine and Biomedical Sciences, University of Yaoundé I, Cameroon

${ }^{2}$ Mechanical Laboratory of ENSET, University of Douala, Cameroon

Submission: January 29, 2020; Published: February 14, 2020

*Corresponding author: Jean Gustave Tsiagadigui , Department of Surgery and Specialties, Faculty of Medicine and Biomedical Sciences, University of Yaoundé I, B.P 1364, Cameroon

\begin{abstract}
The objective of this work was to evaluate thermal conductivity of bone during drilling. More specifically, this involved measuring temperature at varying distances from the drilling point, plotting the temperature evolution over time and as function of the distance to the drilling point and determining the critical areas of temperature peaks harmful to bone tissue. The cortical bones of one-year-old bovine were used, preserved in $9 / 1000$ saline serum at $10^{\circ} \mathrm{C}$. Temperatures were measured at varying distances from the drilling point using a multi thermometer type DT300 with a thermal probe. For each of the average values selected, three tests were carried out using $4 \mathrm{~mm}$ diameter drill bits, for a total of 33 specimens. Temperatures ranging from 33.63 to $38.56^{\circ} \mathrm{C}$ were measured. The highest temperature gradients were observed at $7 \mathrm{~mm}$, the point closest to the drilling focus. These gradients were higher at the end of the drilling. The results of this study allowed us to conclude that the temperature gradient is more important in the vicinity and at the end of the drilling and that it decreases with the distance to the drilling point.

Keywords: Drilling; Bone; Drill bits; Gradient; Temperature
\end{abstract}

\section{Introduction}

The surgical treatment of fractures involves machining the bones, using certain tools such as drill bit, plug, screw or rugine. In addition to their biocompatibility and tissue sterility, they must have mechanical properties that ensure ideal machining of the bone [1]. Bone drilling consists in perforating bone with a drill bit using a manual drilling or a powered tool drill car. To our best knowledge, Carl Hansmann (1886) was the first to introduce drilling in orthopaedics [2]. Currently, this procedure is used in several types of surgery, including arthroplasty, locked nails, plate osteosynthesis, external fixation [3-5]. Ideal drilling requires a proper analysis of mechanical and thermal parameters. At the mechanical point of view, two (02) parameters can guarantee its efficiency: axial force and torque [6-8]. Axial force is determined by feed rate, while the torque is a torsional moment related to the tangential force and the radial distance from the tool center. During drilling, axial force and torque increase until the tool fully penetrates the thickness of the cortical bone, then these parameters stabilize. Several authors have noted the formation of microcracks whose dimensions are influenced by the magnitude of the forces $[9,10]$.

Friction produced during drilling generates heat forces. Temperature gradient during drilling is difficult to avoid and depends on several factors such as bone strength and hardness, applied force, cutting speed, cutting tool geometry, cutting depth and irrigation technique [11]. This gradient may cause necrosis (death of living tissue) especially after exposure to $43^{\circ} \mathrm{C}$ for one hour or $47^{\circ} \mathrm{C}$ for one minute according to the authors [12-15]. In this case, bone very often resorbs around the implant, especially the screw or plug, with loosening and failure of the osteosynthesis [14,16-20]. Many temperature measurement tools are described, but most of them are inaccessible in our context and not always adapted to the bone. The purpose of this study was to evaluate the thermal conductivity of the bone during drilling. More specifically, this involved measuring temperature at varying distances from the 
drilling point, plotting the temperature evolution over time and as a function of the distance to the drilling point and determining critical areas of temperature peaks harmful to bone tissue.

\section{Materials and Methods}

\section{Preparation of Bone Samples}

Three one-year-old (01-year-old) bovine tibias were obtained from butchers, completely mechanically desperiosted. These tibias were stored in the refrigerator in a 9/1000 aqueous saline solution combined with povidone-iodine (Betadine $囚$ ) for 3 days at $10^{\circ} \mathrm{C}$
This temperature was measured using an ambient thermometer. Diaphyseal sections were sampled and reamed until a maximum cortical thickness of $5 \mathrm{~mm}$ was obtained. The bones were immersed in an aqueous solution heated to $37^{\circ} \mathrm{C}$, temperature read by a mercury thermometer. Temperature reading point markings were made respectively at $7 \mathrm{~mm}, 7.5 \mathrm{~mm}, 8 \mathrm{~mm}, 8.5 \mathrm{~mm}$, $9 \mathrm{~mm}, 9.5 \mathrm{~mm}, 10 \mathrm{~mm}, 10.5 \mathrm{~mm}, 11 \mathrm{~mm}, 11.5 \mathrm{~mm}, 12 \mathrm{~mm}$ from the drilling point (Figure 1). The front holes were made to a depth of $2.5 \mathrm{~mm}$ on each sample. All length measurements were made using a 1/50th digital caliper.

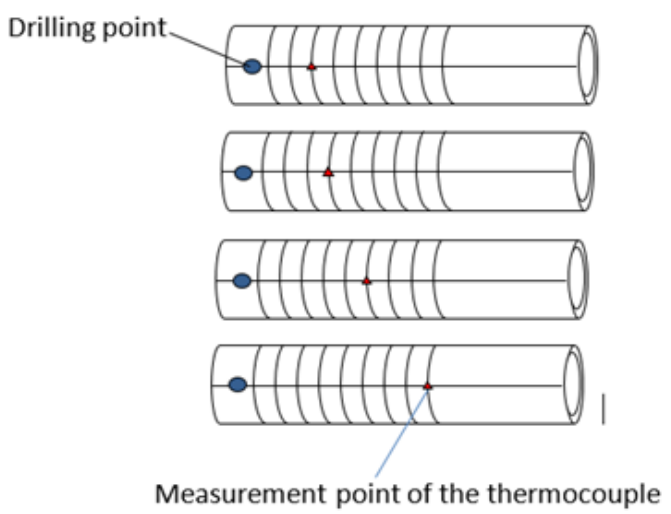

Figure 1: Diagram showing the position of the drilling point (in blue) and the position of the $T^{\circ}$ measuring point (in red) for each sample.

\section{Temperature Measurement}

The DT300 thermometer (Figure 2) is equipped with a $3 \mathrm{~mm}$ diameter thermal probe, $2.5 \mathrm{~mm}$ penetration, $114 \mathrm{~mm}$ long and a $90 \mathrm{~cm}$ connection. It is designed for measurements from $-50^{\circ} \mathrm{C}$ to $300^{\circ} \mathrm{C}$. The display is made in a liquid crystal display (LCD), incorporated with a resolution of $0.1^{\circ} \mathrm{C}$, an accuracy of $\pm 1{ }^{\circ} \mathrm{C}$ and a frequency of $1 / \mathrm{s}$. The device is powered by $2 \times 1.5 \mathrm{~V}$ R03 type
AAA micro batteries. The penetration probe can be removed from the pounch to perform the measurement. Once turned on, the LCD display shows the temperature of the medium in which the probe is located. The displayed temperature can be frozen by pressing the H/T (Hold/Temperature) button. The temperature can also be read after the measurement. The maximum and minimum temperature values are indicated after the start of the measurement using the MIN/MAX button.

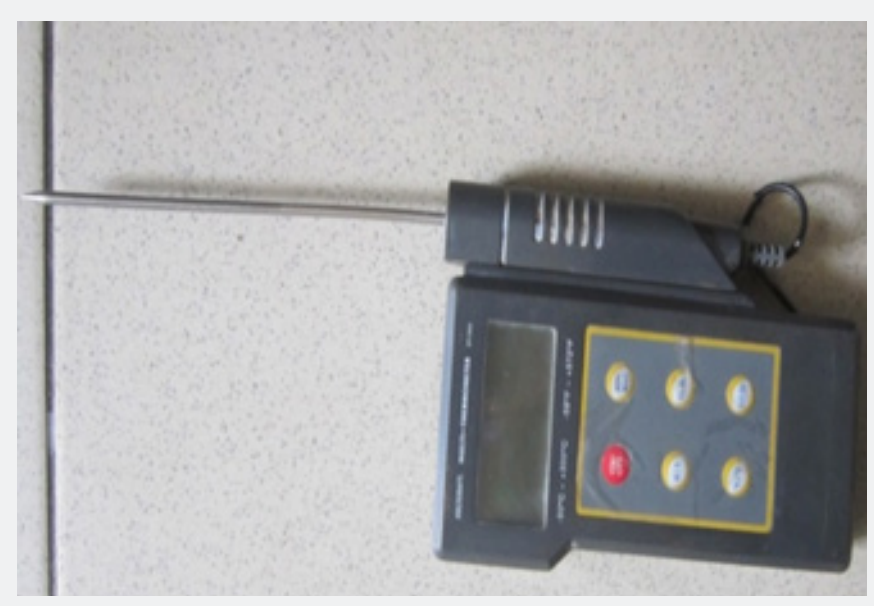

Figure 2: Multi thermometer DT300. 


\section{Drilling}

The 4mm diameter TITEX DB133 carbide monoblock helical drills were used to drill under the following cutting conditions: cutting speed $(\mathrm{Vc})=60 \mathrm{~mm} / \mathrm{min}$, rotation speed $(\mathrm{N})=3821 \mathrm{rpm}$. The advance was manual. The experiment was conducted at the ENSET Mechanical Manufacturing Laboratory in Douala on a Ferm TDM1025 column drill. The bone samples were mounted between the jaws of the drill vice. The drill bit was mounted on the drill chuck. The thermal probe was placed in the front hole and the bone was drilled. Data from the DT300 thermometer were recorded and allowed heat diffusion curves to be plotted. Three tests were performed for each of the distances. A total of 33 bone samples were used for the tests. The average measurements were used.

Results

Table 1: Temperature evolution as a function of time and measurement distance.

\begin{tabular}{|c|c|c|c|c|c|c|c|c|c|c|c|}
\hline \multicolumn{11}{|c|}{ Average Temperature Table } & \\
\hline$X(2)$ & 7 & 7,5 & 8 & 8,5 & 9 & 9,5 & 10 & 10,5 & 11 & 11,5 & 12 \\
\hline T1s & 34,63 & 33,96 & 33,98 & 33,97 & 33,63 & 33,8 & 34,13 & 33,77 & 33,83 & 33,8 & 33,93 \\
\hline $\mathrm{T} 2 \mathrm{~s}$ & 34,9 & 34,13 & 34,09 & 34,03 & 33,7 & 33,8 & 34,17 & 33,8 & 33,83 & 33,83 & 33,97 \\
\hline T3s & 35,13 & 34,3 & 34,21 & 34,13 & 33,73 & 33,9 & 34,23 & 33,8 & 33,83 & 33,9 & 33,97 \\
\hline $\mathrm{T} 4 \mathrm{~s}$ & 35,3 & 34,47 & 34,36 & 34,26 & 33,8 & 33,9 & 34,33 & 33,83 & 33,87 & 33,9 & 33,97 \\
\hline T5s & 35,7 & 34,367 & 34,53 & 34,33 & 33,83 & 34 & 34,43 & 33,87 & 33,9 & 33,9 & 34 \\
\hline T6s & 36,3 & 34,83 & 34,66 & 34,53 & 33,87 & 34,03 & 34,5 & 33,9 & 33,93 & 33,97 & 34,13 \\
\hline T7s & 36,57 & 35,1 & 34,93 & 34,73 & 33,93 & 34,1 & 34,67 & 33,9 & 33,93 & 34 & 34,17 \\
\hline T8s & 37,06 & 35,47 & 35,03 & 34,9 & 34,03 & 34,17 & 34,77 & 33,97 & 33,93 & 34 & 34,17 \\
\hline T9s & 37,4 & 35,6 & 35,3 & 35,07 & 34,13 & 34,2 & 34,83 & 34 & 33,93 & 34,07 & 34,17 \\
\hline T10s & 38 & 35,8 & 35,5 & 35,27 & 34,23 & 34,3 & 35,07 & 34 & 34,03 & 34,07 & 34,17 \\
\hline T11s & 38,56 & 36 & 35,73 & 35,37 & 34,33 & 34,33 & 35,17 & 34,03 & 34,03 & 34,07 & 34,2 \\
\hline
\end{tabular}

年

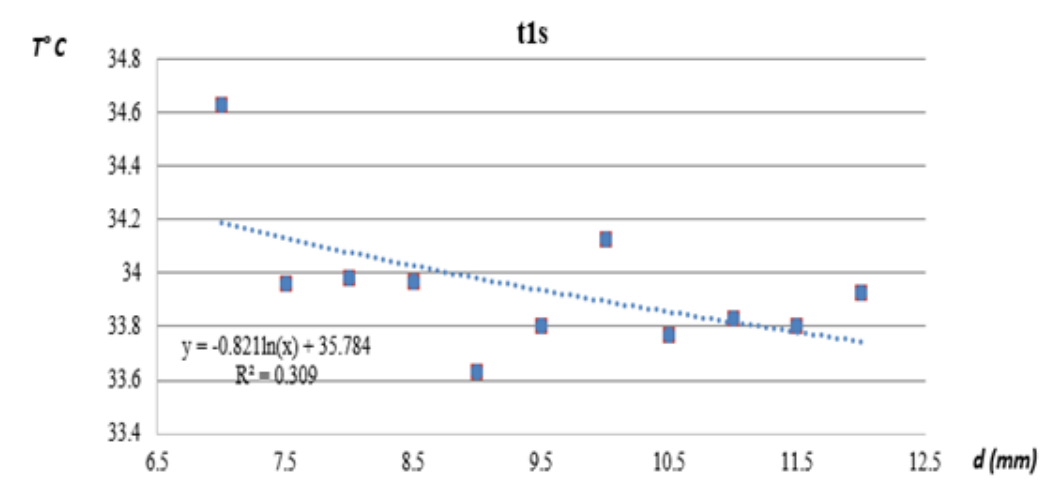

Figure 3: Thermal conduction at the 1st second of the drilling start. 
t3s

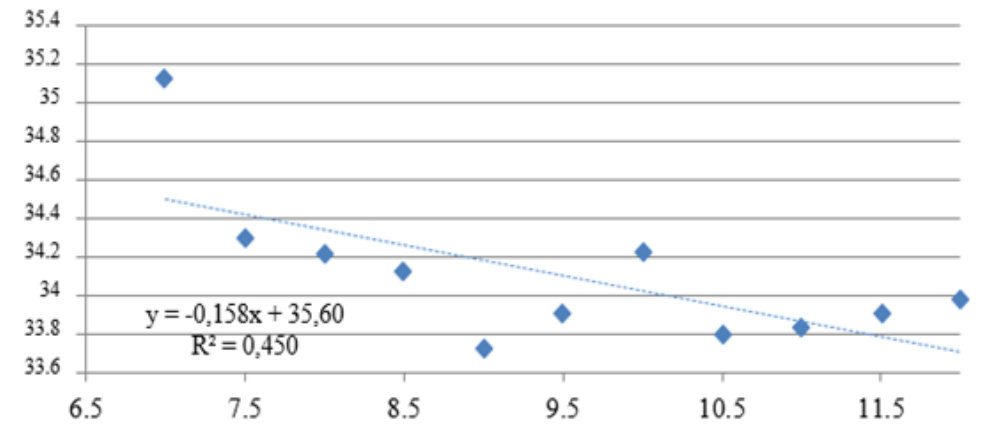

Figure 4: Thermal conduction at the 3rd second of the drilling start.

T11s

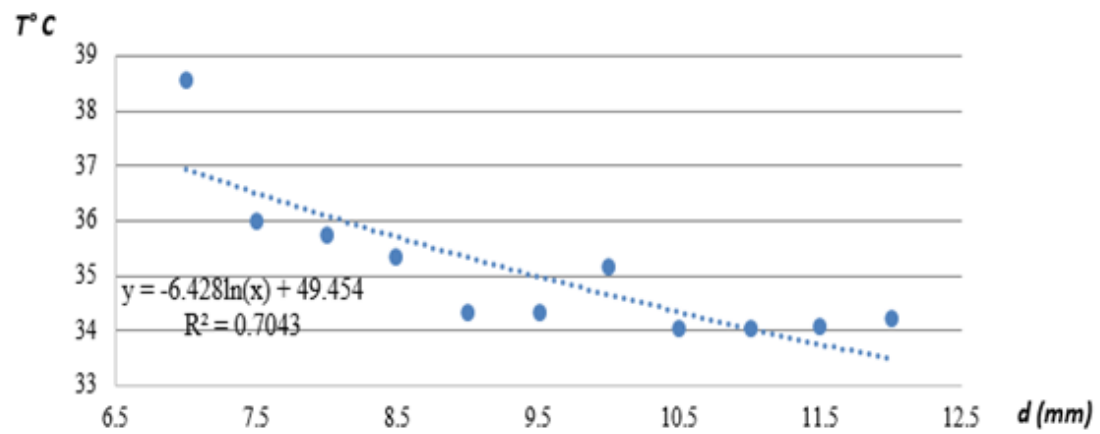

Figure 5: Thermal conduction at the 11th second of the drilling start.

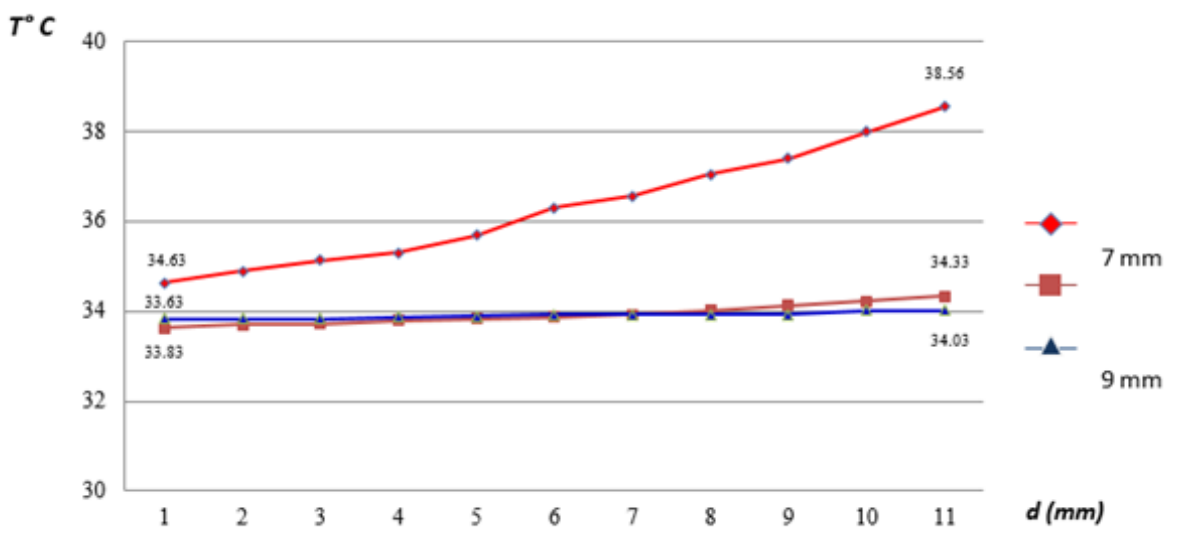

Figure 6: Temperature evolution as a function of distance.

Table 1 shows the temperatures as a function of drilling time and the distance between the measuring point and the drilling point. Temperatures ranging from $33.63^{\circ} \mathrm{C}$ to $38.56^{\circ} \mathrm{C}$ were observed. The temperature gradient increased over time, 
from the beginning to the end of the cut, regardless of the point of measurement. On the other hand, the temperature decreased with the distance between the measuring point and the drilling point (Figures 3-5). The temperature gradient was significant at $7 \mathrm{~mm}$ from the drilling point: as this distance increased, the gradient tended to decrease. The $9 \mathrm{~mm}$ and $11 \mathrm{~mm}$ curves where in plateau and looked the same. At these distances, the gradient was almost zero (Figure 6). Figure 7 shows the temperature evolution as a function of time and drilling point. It shows that the critical point is at the end of the drilling and near the drill. In addition, the gradients were relatively lower at the beginning than at the end of the drilling. The gradient increased significantly as soon as half the cortical thickness was reached, which means that the amount of heat produced during drilling was not constant (Figure 8).

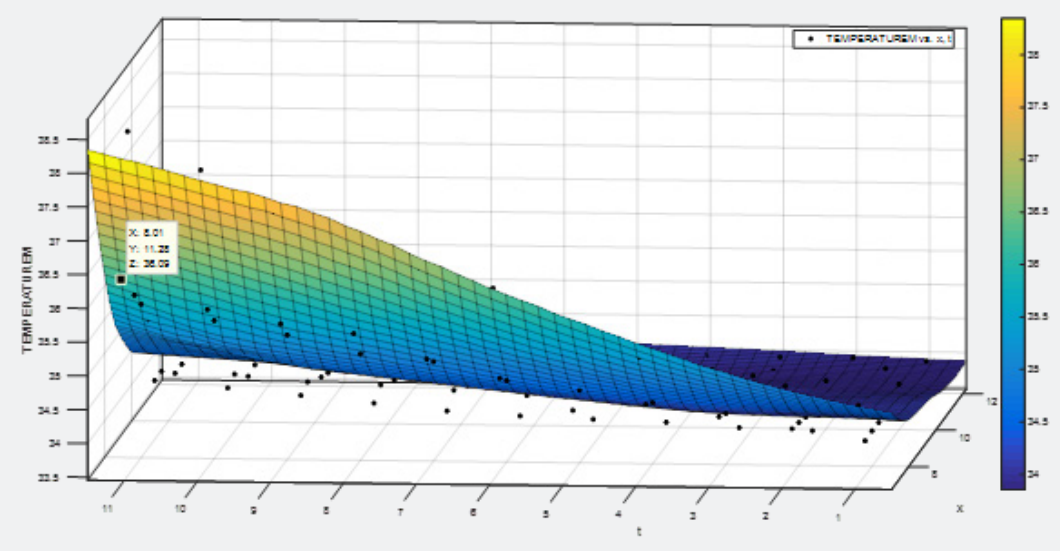

Figure 7: Temperature evolution during drilling.

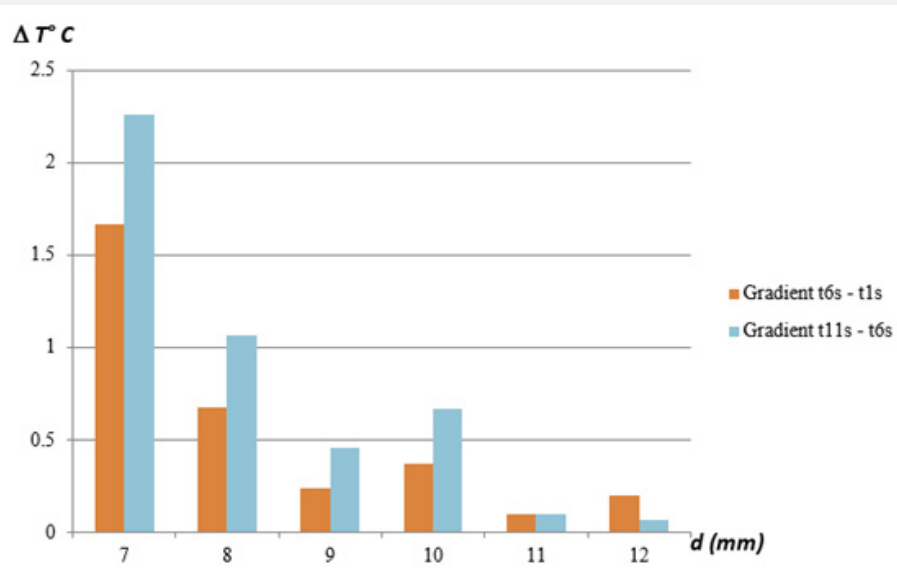

Figure 8: Temperature gradients as a function of distance.

\section{Discussion}

Analysis of the results shows that the highest temperature $\left(38.56^{\circ} \mathrm{C}\right)$ was well below the critical value for the bone cell $\left(47^{\circ} \mathrm{C}\right)$ [12]. This temperature was observed at the measurement point closest to the drilling point. We did not extrapolate the data to the drilling point. It would have been interesting to measure these temperatures as close as possible to the drilling point. The size and stiffness of the DT300 thermometer's thermal probe did not allow this. There is no evidence that temperatures at the drill/ bone interface would have been below the critical threshold of $47^{\circ} \mathrm{C}$ (Figure 7). Burny et al. find different values at $7 \mathrm{~mm}: 31^{\circ} \mathrm{C}$ for $\mathrm{B} 22,26^{\circ} \mathrm{C}$ for $\mathrm{S} 40,40^{\circ} \mathrm{C}$ for $\mathrm{E} 61$ (unthreaded parts) and $28^{\circ} \mathrm{C}$ for $\mathrm{T} 50$. These differences can result from the geometric differences of the tips and that of our drill, on the one hand, and from the very low rotational speed of Burny et al. (60 rpm) [20], on the other hand. These authors were able to measure temperatures at the bone/drill interface. The values are very high for the old B22 drill bits, ranging from $45^{\circ} \mathrm{C}$ to $120^{\circ} \mathrm{C}$. Only the T50 drill bits gives a temperature of $33.7^{\circ} \mathrm{C}$ at this point [20]. 
Thermocouples, despite the cost and necessity of acquisition equipment, are more suitable for studying the temperature distribution around the drilling point. Figures $6 \& 8$ show that measurements at more than $10 \mathrm{~mm}$ from the drilling point is no more suitable, the temperature gradient $\left(\Delta \mathrm{T}^{\circ} \mathrm{C}\right)$ being less than $0.5^{\circ} \mathrm{C}$. This is in line with the results of Burny et al. [21] who measure the temperature between 2 and $10 \mathrm{~mm}$ from the drilling point. It is more interesting to appreciate the heat diffusion in the bone at the end of the drilling than at the beginning, because the correlation value $\left(\mathrm{R}^{2}\right)$ remains below 0.5 until the third second of the drilling (Figures 3-5). The results obtained allow us to say that the thermal conduction in the bone during drilling is "out of equilibrium" (Unsteady-state conduction) [14,19,22,23]. This could be due to an accumulation of bone chips which retain heat by irradiation.

\section{Conclusion}

The DT300 thermometer measures bone temperatures during and around the drilling point. The temperature gradient is greater in the vicinity of the drilling point. This gradient decrease proportionally with the distance to the drilling point and increases with the drilling time. After $10 \mathrm{~mm}$, the gradient is almost zero. The thermal conduction of the bone is weak. The amount of heat emitted by the plug is not constant over time during bone drilling. Measurements with more appropriate instruments should be made in the vicinity of the drilling point.

\section{Authors Contributions}

Jean Gustave TSIAGADIGUI, Vyek Yaya, Benoit Ndiwe, Fabien Ebanda Betene prepared the bone samples, did the experimentations and analyzed the results. Ebenezer Njeugna and Maurice Aurelien Sosso validated the results and the interpretation of the results.

\section{Funding}

This research received no external funding.

\section{Acknowledgment}

We would like to thank Mr. MPAKO Charles, Head of Department of Mechanical Engineering at the IUT of Douala, Cameroon who opened the doors of the Institute's manufacturing laboratory to us for our tests.

\section{Conflicts of Interest}

The authors declare no conflict of interest.

\section{References}

1. Meyrueis P, Cazenave A, Zimmermann R (2004) Biomécanique de l'os. Application au traitement des fractures. EMC Rhumatol Orthop 1(1): 64-93.

2. Karmani S, Lam F (2004) The design and function of surgical drills and K-wires. Curr Orthop 18(6): 484-490.

3. Lee JE, Chavez CL, Park J (2018) Parameters affecting mechanical and thermal responses in bone drilling. J Biomech 71: 4-21.
4. Brown TD, Pedersen DR, Baker KJ, Brand RA (1993) Mechanical consequences of core drilling and bone-grafting on osteonecrosis of the femoral head. J Bone Jt Surg Am 75(9): 1358-1367.

5. Pridie K, Gordon G (1959) A method of resurfacing osteoarthritic knee joints. J Bone Jt Surg 41(3): 618-619.

6. Jacob CH, Berry JT, Pope MH, Hoaglund FT (1976) A study of the bone machining process-Drilling. J Biomech 9(5): 345-349.

7. Wiggins KL, Malkin S (1978) Orthogonal Machining of Bone. J Biomech 100(3): 122-130.

8. Lee J, Gozen BA, Ozdoganlar OB (2012) Modeling and experimentation of bone drilling forces. J Biomech 45(6): 1076-83.

9. Alam K, Mitrofanov AV, Silber Schmidt VV (2011) Experimental investigations of forces and torque in conventional and ultrasonicallyassisted drilling of cortical bone. Med Eng Phys 33(2): 234-239.

10. Singh G, Jain V, Gupta D (2015) Comparative study for surface topography of bone drilling using conventional drilling and loose abrasive machining. Proc Inst Mech Eng 229(3): 225-231.

11. Vishal Gupta, Pulak M Pandey, Vadim V Silberschmidt (2017) Rotary ultrasonic bone drilling: Improved pull out strength and reduced damage. Med Eng Phys 41: 1-8.

12. Augustin G, Zigman T, Davila S, Udiljak T, Staroveski T, et al. (2012) Cortical bone drilling and thermal osteonecrosis. Clin Biomech 27(4): 313-325.

13. Tai BL, Palmisano AC, Belmont B, Irwin TA, Holmes J, et al. (2015) Numerical evaluation of sequential bone drilling strategies based on thermal damage. Med Eng Phys 37(9): 855-861.

14. Dolan EB, Haugh MG, Tallon D, Casey C, McNamara LM (2012) Heatshock-induced cellular responses to temperature elevations occurring during orthopaedic cutting. J R Soc Interf 9(77): 3503-3513.

15. Augustin G, Zigman T, Davila S, Udilljak T, Staroveski T, et al. (2012) Cortical bone drilling and thermal osteonecrosis. Clin Biomech Bristol Avon 27(4): 313-325.

16. Pallan FG (1960) Histological changes in bone after insertion of skeletal fixation pins. J Oral Surg Anesth Hosp Dent Serv 18: 400-408.

17. Matthews LS, Green CA, Goldstein SA (1984) The thermal effects of skeletal fixation-pin insertion in bone. J Bone Jt Surg Am 66(7): 1077-1083.

18. Hillery MT, Shuaib I (2017) Temperature effects in the drilling of human and bovine bone.

19. Hutchinson DT, Bachus KN, Higgenbotham T (2000) External fixation of the distal radius: to predrill or not to predrill. J Hand Surg 25(6): 1064-1068.

20. Burny F (2007) The thermal problem of external fixation pins. World Congress on External Fixation-Cairo.

21. Burny F, Donkerwolcke M, Moulart F, Bourgois, Puers R, et al. (2000) Concept, Design and fabrication of smart orthopedic implants. Med Eng Phys 22: 469-479.

22. Karaca F, Aksakal B (2013) Effects of various drilling parameters on bone during implantology: An in vitro experimental study. Acta Bioeng Biomech 15(4): 25-32.

23. Andrianne Y, Burny F (1993) Les implants filetés de fixation externe: étude des caractéristiques d'insertion et d'ancrage. Etude de la biocompatibilité. 


\section{Your next submission with Juniper Publishers} will reach you the below assets

- Quality Editorial service

- Swift Peer Review

- Reprints availability

- E-prints Service

- Manuscript Podcast for convenient understanding

- Global attainment for your research

- Manuscript accessibility in different formats ( Pdf, E-pub, Full Text, Audio)

- Unceasing customer service

Track the below URL for one-step submission https://juniperpublishers.com/online-submission.php 